\title{
SISTEM PAKAR UNTUK MENDIAGNOSA MASALAH GIZI PADA BALITA DAN IBU HAMIL DENGAN METODE FORWARD CHAINING
}

\author{
Yulisman ${ }^{1)}$, Robbi Datu Muttaqien ${ }^{2)}$ \\ ${ }^{1,2)}$ Sistem Informasi, STMIK Hang Tuah Pekanbaru \\ Jl. Mustafa Sari No. 5 Tangkerang Selatan, Pekanbaru, Riau \\ e-mail: yulismanaziera@yahoo.co.id ${ }^{1)}$, el.moetqy@gmail.com ${ }^{2)}$
}

\begin{abstract}
ABSTRAK
Gizi adalah suatu zat makanan yang diperlukan oleh tubuh yang melalui proses perubahan makanan yang masuk ke dalam tubuh untuk mempertahankan kehidupan. Masalah gizi khususnya gangguan gizi sangat rentan terjadi pada balita dan ibu hamil jika asupan gizinya tidak diberikan dengan baik. Berdasarkan hasil Riset Kesehatan Dasar 2013 (RISKESDAS 2013) jumlah kasus masalah gizi kurang dan gizi buruk pada tahun 2013 sebesar 19,6\% dibandingkan tahun 2007 sebesar 18,4\% dan tahun 2010 sebesar 17,9\%. Faktor-faktor yang menyebabkan terjadinya masalah gizi yaitu ekonomi, lingkungan, kebiasaan buruk dan pengetahuan. Kurangnya pengetahuan masyarakat tentang masalah gizi dan biaya konsultasi yang mahal, sehingga dibutuhkan suatu aplikasi yang dapat membantu kinerja konsultan atau dokter. Aplikasi tersebut berupa sistem pakar untuk mendiagnosa masalah gizi dengan menggunakan metode forward chaining. Metode forward chaining pada sistem pakar merupakan metode yang sering digunakan untuk mendiagnosa penyakit. Dengan adanya aplikasi ini diharapkan dapat membantu kinerja konsultan atau dokter dalam mendiagnosa penyakit masalah gizi, serta memberikan informasi tentang masalah gizi dan pencegahannya.
\end{abstract}

Kata Kunci: Gizi, Balita, Ibu Hamil, Sistem Pakar, Forward Chaining.

\begin{abstract}
Nutrition is a substance food needed by the body through the process of changing food entered the body to sustain life. Nutritional issues in particular are very susceptible nutritional disorder occurs in toddlers and pregnant mothers if the nutritional intake is not given well. Based on the results of Basic Health Research 2013 (RISKESDAS 2013) the number of cases of malnutrition and the problem of malnutrition in 2013 amounted to $19.6 \%$ compared to 2007 by $18.4 \%$ and in 2010 by 17.9\%. Factors that cause nutritional problems of economy, environment, bad habits and knowledge. The lack of public knowledge about nutrition problems and consultancy fees are expensive, so it needed an application that can help performance of consultant or doctor. The application of an expert system to diagnose nutritional problems by using forward chaining method. A method of forward chaining in expert system is the method often used to diagnose disease. With this application is expected to assist the performance of consultants or doctors to diagnose disease nutrition problems, as well as provide information on nutrition issues and prevention.
\end{abstract}

Keywords: Nutrition, Toddler, Pregnant Woman, Expert System, Forward Chaining.

\section{PENDAHULUAN}

Gizi merupakan zat yang dibutuhkan oleh tubuh yang diperoleh dari makanan dan digunakan untuk pertumbuhan, pemeliharaan, dan perbaikan jaringan tubuh sehingga dapat menentukan kualitas tumbuh kembang balita sebagai sumber daya manusia yang akan datang.

Masalah gizi khususnya gangguan gizi sangat rentan terjadi pada balita dan ibu hamil jika asupan gizinya tidak diberikan dengan baik. Berdasarkan hasil Riset Kesehatan Dasar 2013 (RISKESDAS 2013) jumlah kasus masalah gizi kurang dan gizi buruk pada tahun 2013 sebesar 19,6\% dibandingkan tahun 2007 sebesar 18,4 \% dan tahun 2010 sebesar 17,9\% [3].

Menurut Proverawati di Indonesia masalah gizi dikelompokkan menjadi 2 kelompok yaitu kekurangan energi dan protein (KEP) merupakan masalah gizi makro, sedangkan anemia gizi besi (AGB), kekurangan vitamin A (KVA), dan gangguan akibat kekurangan yodium (GAKY) merupakan masalah gizi mikro [1].

Faktor-faktor yang menyebabkan terjadinya gangguan gizi, kemiskinan atau ekonomi merupakan faktor utama yang menjadi penyebab terjadinya masalah gizi di Indonesia, meskipun ada beberapa faktor lainnya seperti kurangnya pengetahuan, kebiasaan buruk, dan lingkungan kotor. Dengan dirancangnya sistem pakar sehingga dapat menambah pengetahuan kepada masyarakat.

Sistem pakar merupakan suatu program komputer yang mengandung pengetahuan dari satu atau lebih pakar manusia mengenai suatu bidang yang spesifik. Menurut Martin dan Oxman Sistem pakar adalah sistem berbasis 
komputer yang menggunakan pengetahuan, fakta, dan teknik penalaran dalam memecahkan masalah yang biasanya hanya dapat dipecahkan oleh seorang pakar dalam bidang tersebut [6].

Sistem pakar adalah aplikasi berbasis komputer yang digunakan untuk menyelesaikan masalah sebagaimana yang dipikirkan oleh pakar [7].

Menurut Giarattano dan Riley Metode forward chaining berarti menggunakan himpunan aturan kondisi-aksi, data di dalam aturan ini digunakan untuk menentukan mana yang akan dijalankan. Metode forward chaining digunakan untuk menangani masalah pengendalian dan peramalan [6].

Dari pemaparan latar belakang di atas, dapat dijadikan landasan dapat ditenentukan rumusan masalah dalam penelitian yang dilakukan. Rumusan masalahnya adalah bagaimana mengatasi masalah biaya konsultasi masalah gizi ke dokter atau konsultan gizi dan rumusan masalah selanjutnya bagaimana aplikasi sistem pakar untuk mendiagnosa masalah gizi pada balita dan ibu hamil dapat memberikan kemudahan informasi masalah gizi dimana pun dan kapan pun. Rumusan yang bisa ditetapkan berikutnya bagaimana menjelaskan pengetahuan tentang penyakit masalah gizi pada balita dan ibu hamil kepada masyarakat menggunakan sistem pakar.

Berdasarkan uraian permasalahan dan rumusan masalah maka dapat ditentukan tujuan dari penelitian ini adalah merancang sistem pakar untuk mendiagnosa masalah gizi pada balita dan ibu hamil dan menerapkan metode forward chaining untuk mendiagnosa masalah gizi serta menjelaskan cara mendiagnosa masalah gizi dengan menggunakan sistem pakar.

\section{A. Struktur Sistem Pakar}

Komponen-komponen yang ada pada sistem pakar ditunjukkan oleh Gambar 1 [2]:

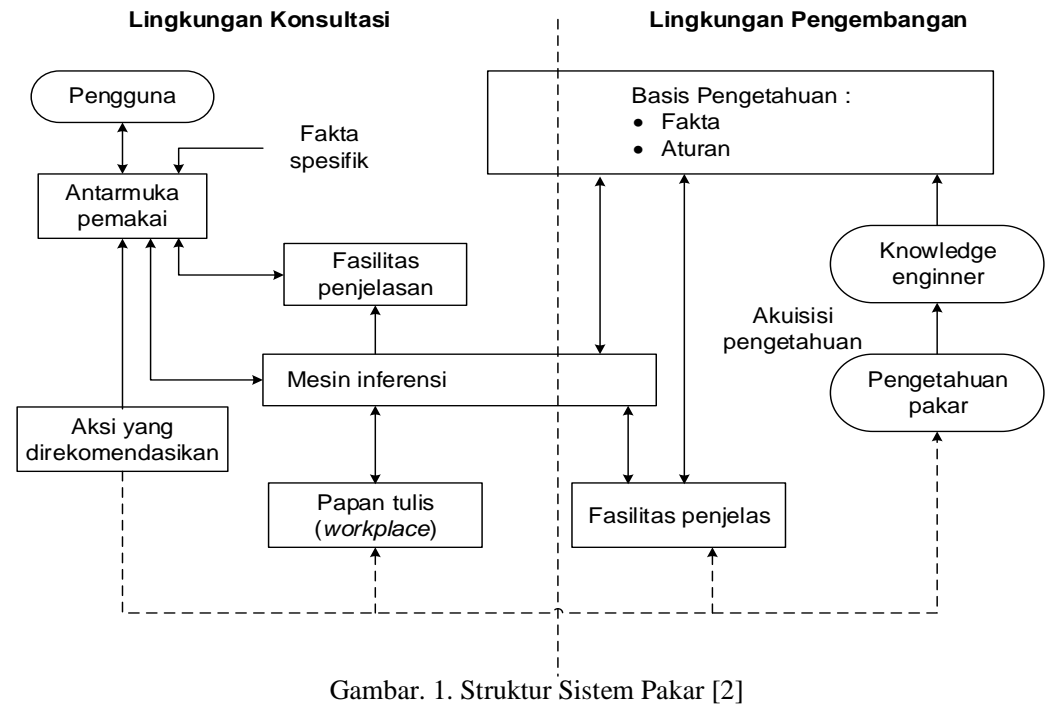

1. Sub sistem penambahan pengetahuan. Bagian ini digunakan untuk memasukkan pengetahuan, mengkronstruksi atau memperluas pengetahuan dalam basis pengetahuan.

2. Basis pengetahuan. Berisi pengetahuan-pengetahuan yang dibutuhkan untuk memahami, memformulasikan dan menyelesaikan masalah.

3. Mesin inferensi (inference engine). Program yang berisi metodologi yang digunakan untuk melakukan penalaran terhadap informasi-informasi dalam basis pengetahuan dan blackboard, serta digunakan untuk memformulasikan konklusi.

4. Papan tulis (Blackboard). Merupakan area dalam memori yang digunakan untuk merekam kejadian yang sedang berlangsung termasuk keputusan sementara.

5. Antarmuka. Digunakan untuk media komunikasi antara pengguna (user) dan program.

6. Fasilitas penjelasan. Digunakan untuk melacak respon dan memberikan penjelasan tentang kelakuan sistem pakar secara interaktif melalui pertanyaan.

7. Akuisisi pengetahuan. Sistem ini digunakan untuk mengevaluasi kinerja sistem pakar.

\section{B. Masalah Gizi}

Gizi adalah elemen yang terdapat dalam makanan dan dapat dimanfaatkan secara langsung oleh tubuh seperti halnya karbohidrat, protein, lemak, vitamin, mineral, dan air. 
Masalah gizi memiliki dampak yang luas, tidak saja terhadap kesakitan, kecacatan, dan kematian, tetapi juga terhadap pembentukan sumber daya manusia (SDM) yang berkualitas dengan produktifitas optimal.

Kecukupan gizi ibu selama hamil hingga anak berusia di bawah 5 tahun serta pola pengasuhan yang tepat akan memberikan kontribusi nyata dalam mencetak generasi unggul.

Masalah gizi di Indonesia dikelompokkan atas 2 kelompok, yaitu masalah gizi makro dan masalah gizi mikro. Kekurangan energi protein merupakan masalah gizi makro, sedangkan anemia gizi besi (AGB), kekurangan vitamin A (KVA) dan gangguan akibat kekurangan yodium (GAKY) merupakan masalah gizi mikro :

1. Kurang Energi Protein (KEP)

Kekurangan Energi Protein akan terjadi jika kebutuhan tubuh akan kalori, protein atau keduanya tidak tercukupi. Kedua bentuk kekurangan (defisiensi) ini tidak jarang berjalan bersamaan, meskipun salah satu lebih dominan dibandingkan yang lain. Kekurangan energi protein mempunyai gejala seperti kegagalan pertumbuhan, berat badan rendah, kecil atau pendek (kadang-kadang seperti normal), kurus atau kurus sekali, dan bengkak (oedem).

2. Anemia Gizi Besi (AGB)

Anemia menyebabkan berkurangnya jumlah sel darah merah atau jumlah hemoglobin dalam sel darah merah, sehingga darah tidak dapat mengangkut oksigen dalam jumlah sesuai yang diperlukan tubuh. Gejala yang ditimbulkan jika terkena anemia gizi besi adalah pucat, penurunan penampilan fisik, gangguan kognitif (kesadaran), kegagalan pertumbuhan, penurunan penampilan (letih, lemah, lunglai, lemas, dan lesu).

3. Kekurangan Vitamin A (KVA)

Keadaan dimana simpanan vitamin A dalam tubuh yang sebagian besar terdapat dalam hati menjadi sangat kurang. Sehingga timbul tanda dan gejala fisik, klinis, dan subklinis yang dapat dideteksi. Gejalanya adalah buta senja, gangguan pada kulit, penurunan daya tahan tubuh, dan kegagalan pertumbuhan.

4. Gangguan Akibat Kekurangan Yodium (GAKY)

Yodium diperlukan tubuh untuk mengatur pertumbuhan dan perkembangan mulai dari janin sampai dewasa. Kekurangan yodium pada tingkat berat dapat mengakibatkan cacat fisik dan mental seperti tuli, bisu tuli, pertumbuhan badan terganggu, badan lemah, kecerdasan dan perkembangan mental terganggu.

\section{METODE PENELITIAN}

\section{A. Tahapan Penelitian}

Model air terjun (waterfall) merupakan model klasik yang bersifat sistematis, berurutan dalam membangun software. Metode air terjun (waterfall) merupakan suatu proses yang terstruktur dan berurutan, dimulai dari requirments definition, system and software design, implementation and unit testing, integration and system testing, dan operational and maintenance, metode ini sangat cocok untuk pembuatan aplikasi berskala besar karena menyangkut manajemen dan sistem yang rumit [5]. Tahapan metode waterfall menurut Sommerville akan dijelaskan pada Gambar 2.

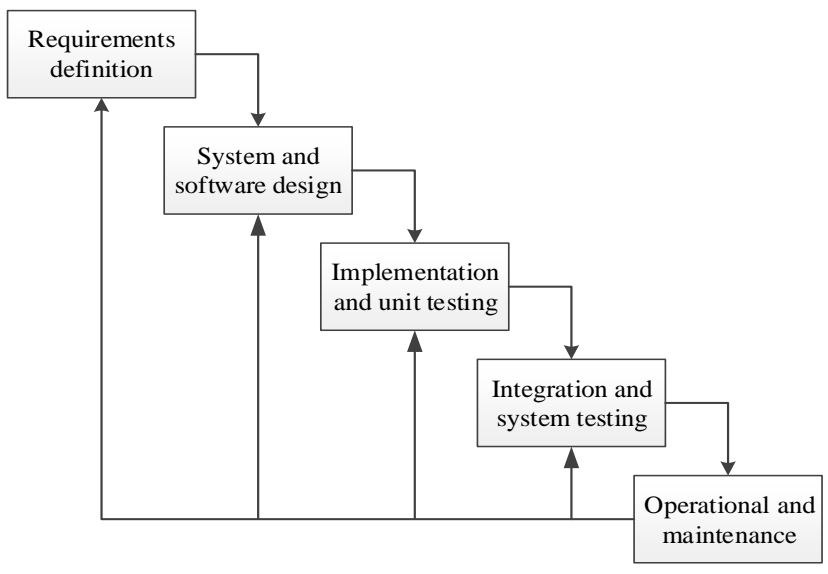

Gambar. 2. Waterfall [5]

1. Definisi Kebutuhan (Requirements Definition)

Sistem layanan, batasan, dan tujuan yang ditetapkan dengan berkonsultasi dengan pengguna sistem, kemudian didefinisikan secara rinci dan berfungsi sebagai spesifikasi sistem. 
2. Desain Sistem dan Perangkat Lunak (System and Software Design)

Perancangan proses sistem yang mengalokasikan persyaratan untuk perangkat keras atau perangkat lunak sistem dengan membentuk arsitektur sistem secara keseluruhan. Perancangan perangkat lunak melibatkan identifikasi dan menggambarkan abstraksi sistem perangkat lunak dasar dan relasinya.

3. Penerapan dan Pengujian Unit (Implementation and Unit Testing)

Pada tahapan ini, peranangan perangkat lunak direalisasikan sebagai sekumpulan program atau unit program. Unit pengujian melakukan verifikasi bahwa setiap unit telah memenuhi spesifikasinya.

4. Integrasi dan Pengujian Sistem (Integration and System Testing)

Unit program individu atau program yang terintegrasi dan teruji sebagai sistem secara lengkap untuk memastikan bahwa kebutuhan perangkat lunak sudah terpenuhi. Setelah pengujian, sistem perangkat lunak diserahkan kepada pelanggan.

5. Pengoperasian dan Pemeliharaan (Operational and Maintenance)

Pada umumnya hal ini merupakan fase siklus hidup terpanjang. sistem dipasang serta dimasukkan ke dalam penggunaan praktis. Pemeliharaan memperbaiki kesalahan yang tidak ditemukan pada tahap-tahap awal dari siklus hidup, perbaikan pelaksanaan unit sistem serta meningkatkan layanan sistem sebagai kebutuhan baru yang ditemukan.

\section{B. Analisis Sistem}

Permasalahan yang akan dibahas adalah membuat suatu sistem berdasarkan data yang diperoleh dari pakar dalam hal ini Bapak Sahat Hutagaol, SKM, MPS. Untuk mendiagnosa masalah gizi diperlukan konsultasi ke konsultan gizi, namun karena biaya konsultasi sangat mahal, maka perlu dibuatkan suatu program komputer berupa sistem pakar. Penerapan sistem pakar masalah gizi meliputi pengumpulan gejala, penyakit dan pencegahannya.

Tahapan analisis sistem mencoba menganalisis sistem yang ada pada sistem pakar masalah gizi. Untuk mengidentifikasi dan memberikan solusi terhadap masalah yang ada, pertama peneliti mencoba menganalisa menggunakan metode analisis PIECES (Performance, Information, Economy, Control, Efficiency and Service). Berikut ini adalah hasil analisa terhadap sistem pakar untuk diagnosis masalah gizi pada balita dan ibu hamil dengan metode forward chaining dengan menggunakan analisis PIECES:

1. Performance (Kinerja)

Kinerja pada sistem pakar mendiagnosa masalah gizi dengan metode forward chaining ini memiliki kinerja yang dapat memberikan informasi diagnosa masalah gizi dan pencegahannya secara cepat kepada pasien (user) mengenai masalah gizi.

2. Information (Informasi)

Informasi merupakan hal yang penting karena dengan informasi yang didapat dari sistem pakar mendiagnosa masalah gizi ini memberikan informasi yang baik dimana informasi yang dihasilkan dapat memenuhi keinginan dari pasien (user) dan juga informasi ini dapat dimanfaatkan untuk mengatasi masalah-masalah yang dihadapi.

3. Economic (Ekonomi)

Pada dasarnya ekonomi berkaitan dengan biaya. Pijakan dasar bagi seseorang adalah biaya yang murah. Sistem pakar mendiagnosa masalah gizi dapat menghemat biaya konsultasi dengan mengetahui gejala penyakitnya dan memberikan informasi pencegahan.

4. Control (Kendali)

Sistem pakar mendiagnosa masalah gizi ini telah memiliki kontrol yang baik dimana selain dapat memproses data dengan teliti, sistem pakar ini juga mudah diakses oleh pasien (user).

5. Effenciency (Efesiensi)

Efisiensi berhubungan dengan bagaimana sumber tersebut dapat digunakan secara optimal. Sistem pakar mendiagnosa masalah gizi ini memiliki efisiensi yang baik karena dengan adanya sistem pakar ini dapat membantu user dalam mendiagnosa masalah gizi dengan lebih cepat dan sesuai dengan yang diharapkan.

6. Service (Pelayanan)

Untuk meningkatkan kepuasan kepada pengguna, sistem pakar diagnosa masalah gizi pada balita dan ibu hamil telah memberikan layanan yang baik kepada pengguna, karena sistem pakar dapat memberikan jawaban yang lebih tepat dan cepat.

\section{Representasi Pengetahuan}

Sistem diagnosa yang akan dibuat adalah sistem diagnosa aturan. Pengetahuan direpresentasikan dengan menggunakan aturan bentuk IF-THEN. Sistem diagnosa bekerja untuk mendapatkan solusi pencegahan berdasarkan gejala-gejala awal yang dirasakan. Representasi pengetahuan yang digunakan yaitu tabel penyakit ditunjukkan oleh Tabel I, tabel gejala ditunjukkan oleh Tabel II, pohon gejala dan jenis penyakit yang diderita. 
Yulisman dan Muttaqien — Sistem Pakar Untuk Mendiagnosa Masalah Gizi Pada Balita Dan Ibu Hamil Dengan Metode Forward Chaining

TABEL I

JENIS PENYAKIT MASALAH GIZI

\begin{tabular}{ccl}
\hline \hline No & Kode Penyakit & \multicolumn{1}{c}{ Nama Penyakit } \\
\hline 1 & P001 & Kekurangan Energi Protein (KEP) \\
2 & P002 & Anemia Gizi Besi (AGB) \\
3 & P003 & Kekurangan Vitamin A (KVA) \\
4 & P004 & GAKY Neurological Cretinism \\
5 & P005 & GAKY Hyperthyroid Cretinism \\
\hline
\end{tabular}

TABEL II.

GeJala PENYAKIT MASAlah Gizi

\begin{tabular}{ccl}
\hline \hline No & Kode Gejala & \multicolumn{1}{c}{ Gejala Yang Dirasakan } \\
\hline 1 & G001 & Kegagalan pertumbuhan \\
2 & G002 & Berat badan rendah \\
3 & G003 & Kecil atau pendek, kadang-kadang seperti normal \\
4 & G004 & Kurus atau kurus sekali \\
5 & G005 & Oedem atau bengkak \\
6 & G006 & Pucat \\
7 & G007 & Penurunan tampilan fisik \\
8 & G008 & Gangguan kesadaran (kognitif) \\
9 & G009 & Tubuh lemah \\
10 & G010 & Buta senja \\
11 & G011 & Gangguan pada kulit \\
12 & G012 & Penurunan daya tahan tubuh \\
13 & G013 & Pembengkakan kelenjar gondok \\
14 & G014 & Bisu tuli \\
15 & G015 & Juling atau squint \\
16 & G016 & Gangguan mental berat \\
17 & G017 & Makan tidak baik \\
18 & G018 & Susah buang air besar (konstipasi) \\
19 & G019 & Kedinginan \\
20 & G020 & Mengantuk \\
21 & G021 & Kulit tebal kering \\
22 & G022 & Menangis parau \\
23 & G023 & Hambatan mental \\
\hline \hline
\end{tabular}

D. Perancangan Basis Aturan (Rule Base)

Fakta yang ditemukan dalam permasalahan masalah gizi pada balita dan ibu hamil ditunjukkan pada Tabel III:

TABEL III.

RULE BASE

\begin{tabular}{cll}
\hline \hline Aturan & \multicolumn{1}{c}{ Gejala } & \multicolumn{1}{c}{ Penyakit } \\
\hline Rule 1 & IF G001 AND G002 AND G003 AND G004 AND G005 & Kekurangan Energi Protein (P001) \\
Rule 2 & IF G001 AND G006 AND G007 AND G008 AND G009 & Anemia Gizi Besi (P002) \\
Rule 3 & IF G001 AND G010 AND G011 AND G012 & Kekurangan Vitamin A (P003) \\
Rule 4 & IF G009 AND G013 AND G014 AND G015 AND G016 & GAKY Neurological Cretinism (P004) \\
Rule 5 & IF G001 AND G013 AND G017 AND G018 AND G019 AND G020 AND & GAKY Hypothyroid Cretinism (P005) \\
& G021 AND G022 AND G023 & \\
\hline
\end{tabular}

Setelah fakta-fakta dari sumber didapatkan selanjutnya dilakukan penyusunan fakta-fakta tersebut ke arah yang lebih terstruktur seperti ditunjukkan pada Tabel IV.

TABEL IV.

BASIS PENGETAHUAN

\begin{tabular}{|c|c|c|c|c|c|c|}
\hline No & $\begin{array}{l}\text { Penyakit } \\
\text { jala }\end{array}$ & Kekurangan Energi Protein & $\begin{array}{l}\text { Anemia Gizi } \\
\text { Besi }\end{array}$ & $\begin{array}{c}\text { Kekurangan } \\
\text { Vitamin A }\end{array}$ & $\begin{array}{l}\text { GAKY Neurological } \\
\text { Cretinism }\end{array}$ & $\begin{array}{c}\text { GAKY Hypothyroid } \\
\text { Cretinism }\end{array}$ \\
\hline 1 & GP1 & $\sqrt{ }$ & $\sqrt{ }$ & $\sqrt{ }$ & & $\sqrt{ }$ \\
\hline 2 & GP2 & $\sqrt{ }$ & & & & \\
\hline 3 & GP3 & $\sqrt{ }$ & & & & \\
\hline 4 & GP4 & $\sqrt{ }$ & & & & \\
\hline 5 & GP5 & $\sqrt{ }$ & & & & \\
\hline 6 & GP6 & & $\sqrt{ }$ & & & \\
\hline 7 & GP7 & & $\sqrt{ }$ & & & \\
\hline 8 & GP8 & & $\sqrt{ }$ & & & \\
\hline 9 & GP9 & & $\sqrt{ }$ & & $\sqrt{ }$ & \\
\hline 10 & GP10 & & & $\sqrt{ }$ & & \\
\hline 11 & GP11 & & & $\sqrt{ }$ & & \\
\hline 12 & GP12 & & & $\sqrt{ }$ & & \\
\hline 13 & GP13 & & & & $\sqrt{ }$ & $\sqrt{ }$ \\
\hline 14 & GP14 & & & & $\sqrt{ }$ & \\
\hline
\end{tabular}




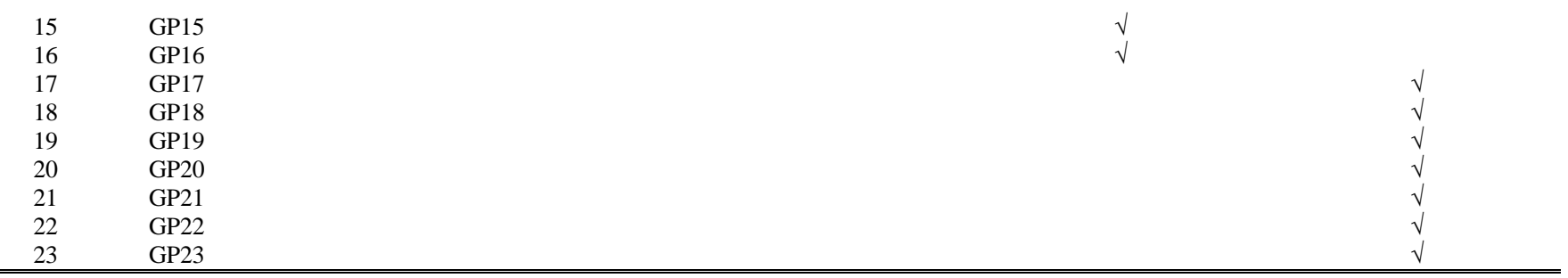

\section{E. Pohon Keputusan (Decision Tree)}

Pohon yang dalam analisis pemecahan masalah pengambilan keputusan data gejala, data penyakit dan pencegahan diperoleh, selanjutnya pohon keputusan tersebut juga memperlihatkan faktor-faktor kemungkinan yang akan mempengaruhi alternatif-alternatif keputusan tersebut, disertai dengan penilaian hasil akhir yang akan didapat bila mengambil alternatif keputusan tersebut seperti ditunjukkan pada Gambar 3.

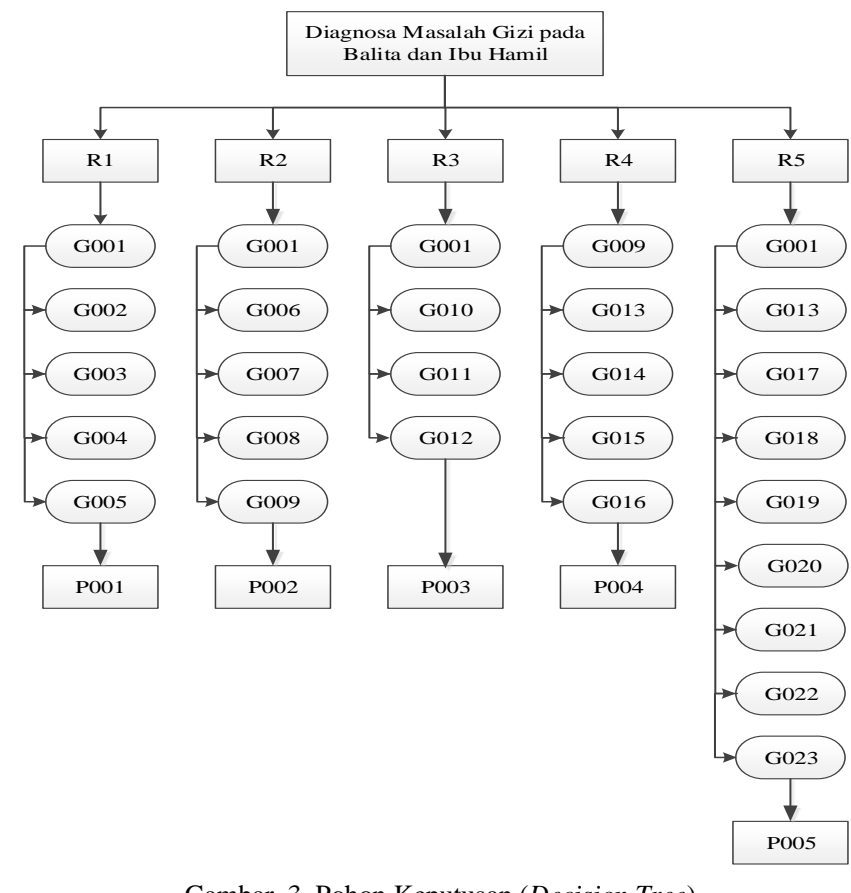

Gambar. 3. Pohon Keputusan (Decision Tree)

\section{HASIL DAN PEMBAHASAN}

\section{A. Perancangan Sistem}

Tujuan perancangan sistem adalah memberikan gambaran secara umum kepada pengguna (user), serta memudahkan pengguna dalam mendiagnosa masalah gizi pada balita dan ibu hamil.

Unified Modelling Language (UML) merupakan sebuah "bahasa" yang telah menjadi standar dalam industri untuk visualisasi, merancang dan mendokumentasikan sistem piranti lunak. Unified Modelling Language menawarkan sebuah standar untuk merancang model sebuah sistem.

Menurut Marlyaningrum Unified Modelling Language adalah keluarga notasi grafis yang didukung oleh metamodel tunggal, yang membantu pendeskripsian dan desain sistem yang dibangun menggunakan pemograman berorientasi objek [8].

\section{Diagram Use Case (Use Case Diagram)}

Menurut Satzinger use case adalah sebuah kegiatan yang dilakukan oleh sistem biasanya dalam menanggapi permintaan dari pengguna system [4]. Diagram use case digunakan untuk mengetahui fungsi apa saja yang ada di dalam sebuah sistem dan siapa saja yang berhak menggunakan fungsi-fungsi tersebut. Yang ditekankan pada diagram ini adalah "apa" yang diperbuat sistem, dan bukan "bagaimana". Use case memiliki simbol yang digunakan untuk mendefinisikan interaksi antara satu atau lebih aktor dengan sistem yang akan dirancang. Diagram Usecase dari sistem yang dibangun dapat dilihat pada Gambar 4. 


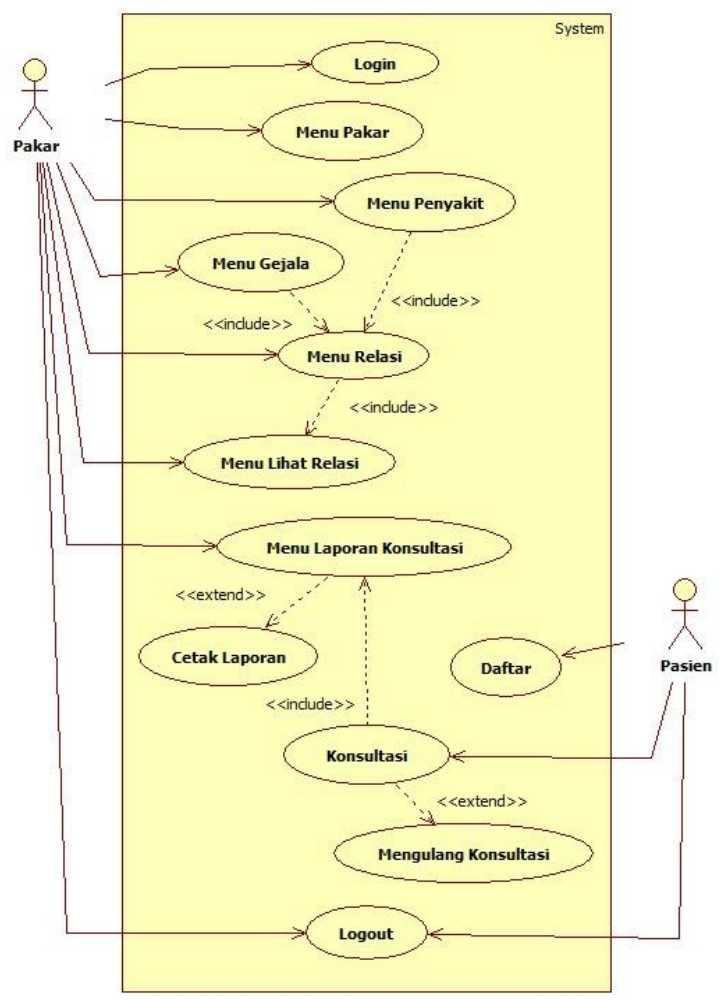

Gambar. 4. Diagram Use Case

2. Diagram Aktivitas (Activity Diagram)

Diagram aktivitas (activity diagram) menurut Satzinger adalah sebuah diagram alur kerja yang menjelaskan berbagai kegiatan pengguna atau sistem, orang yang melakukan masing-masing aktivitas, dan aliran sekuensial dari aktivitas-aktivitas tersebut [4]. Diagram aktivitas dari sistem yang dibangun dapat dilihat pada Gambar 5-11.

a. Diagram Aktivitas Pasien

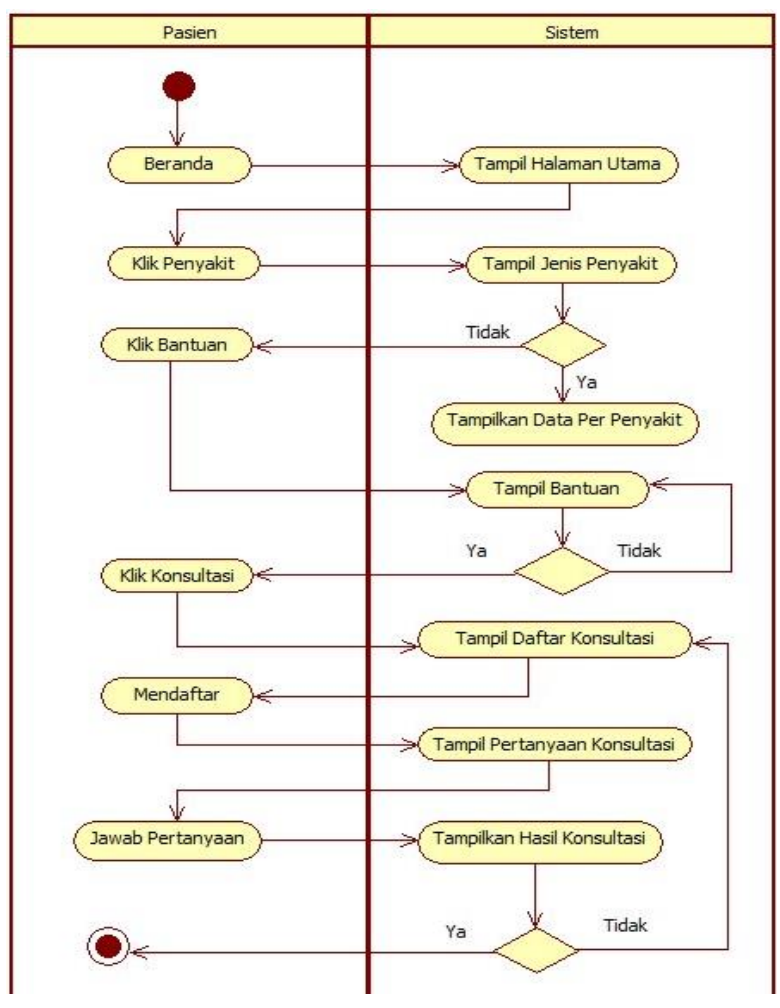

Gambar. 5. Diagram Aktivitas Pasien b. Diagram Aktivitas Pakar

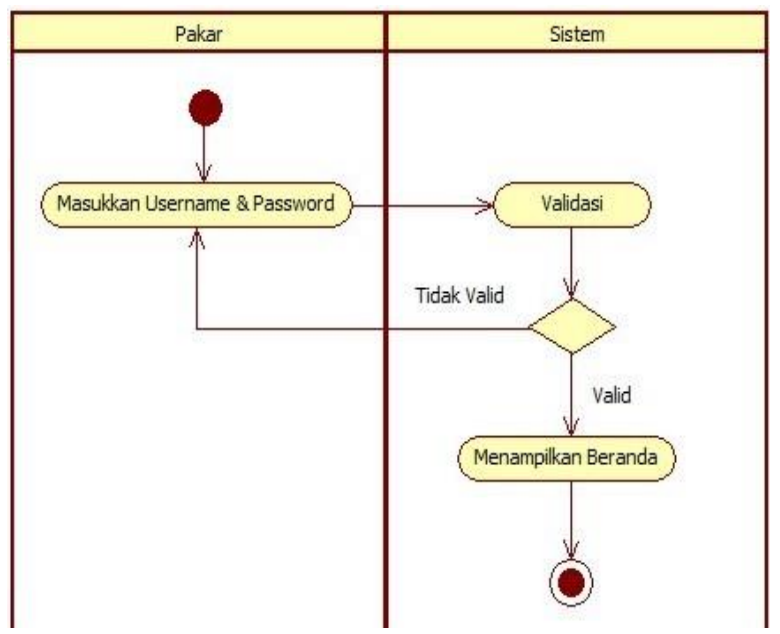

Gambar. 6. Diagram Aktivitas Login Pakar 
c. Diagram Aktivitas Menu Pakar

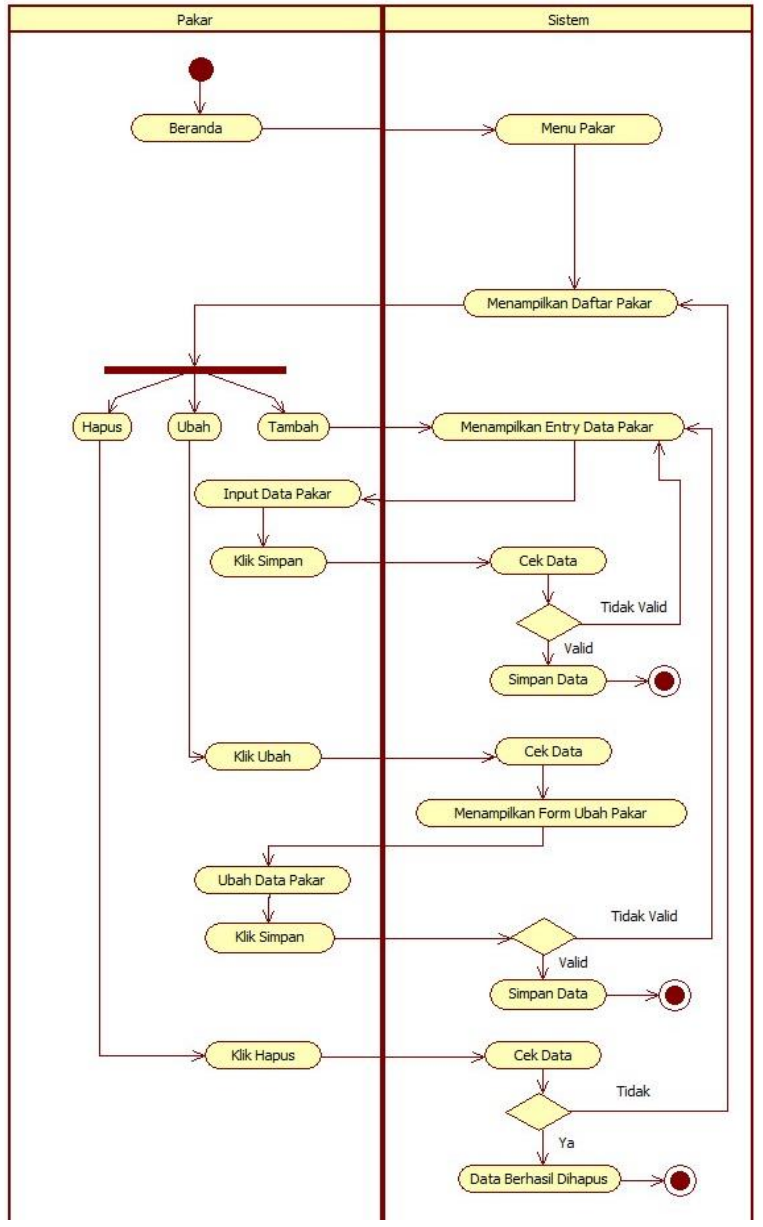

Gambar. 7. Diagram Aktivitas Menu Pakar

e. Diagram Aktivitas Menu Gejala

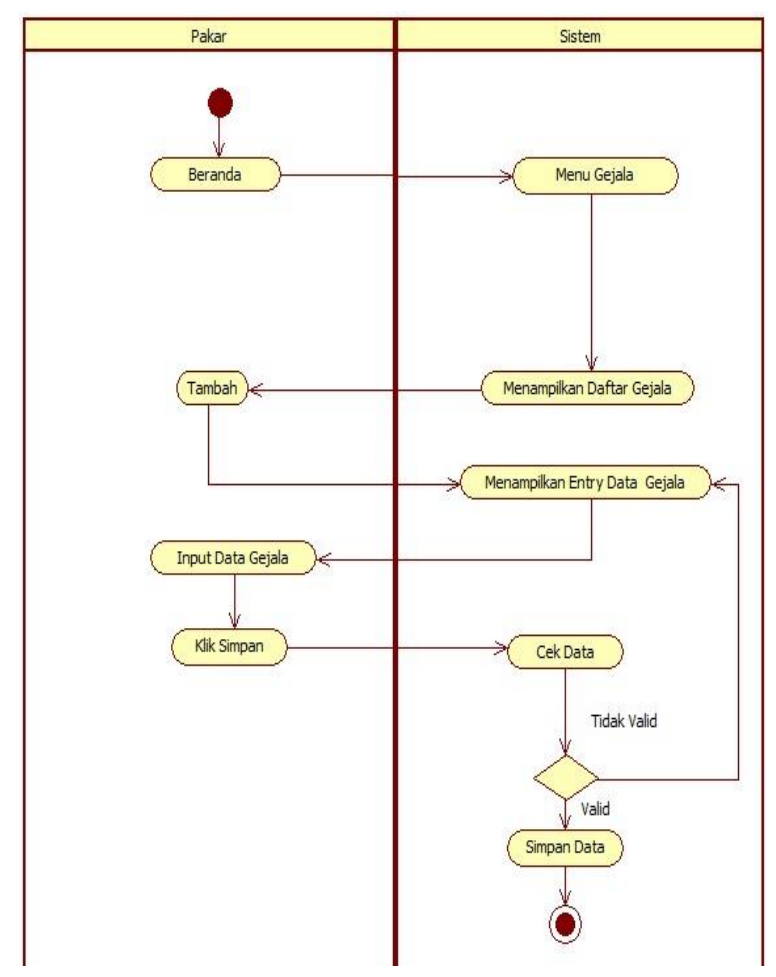

Gambar. 9. Diagram Aktivitas Menu Gejala d. Diagram Aktivitas Menu Penyakit

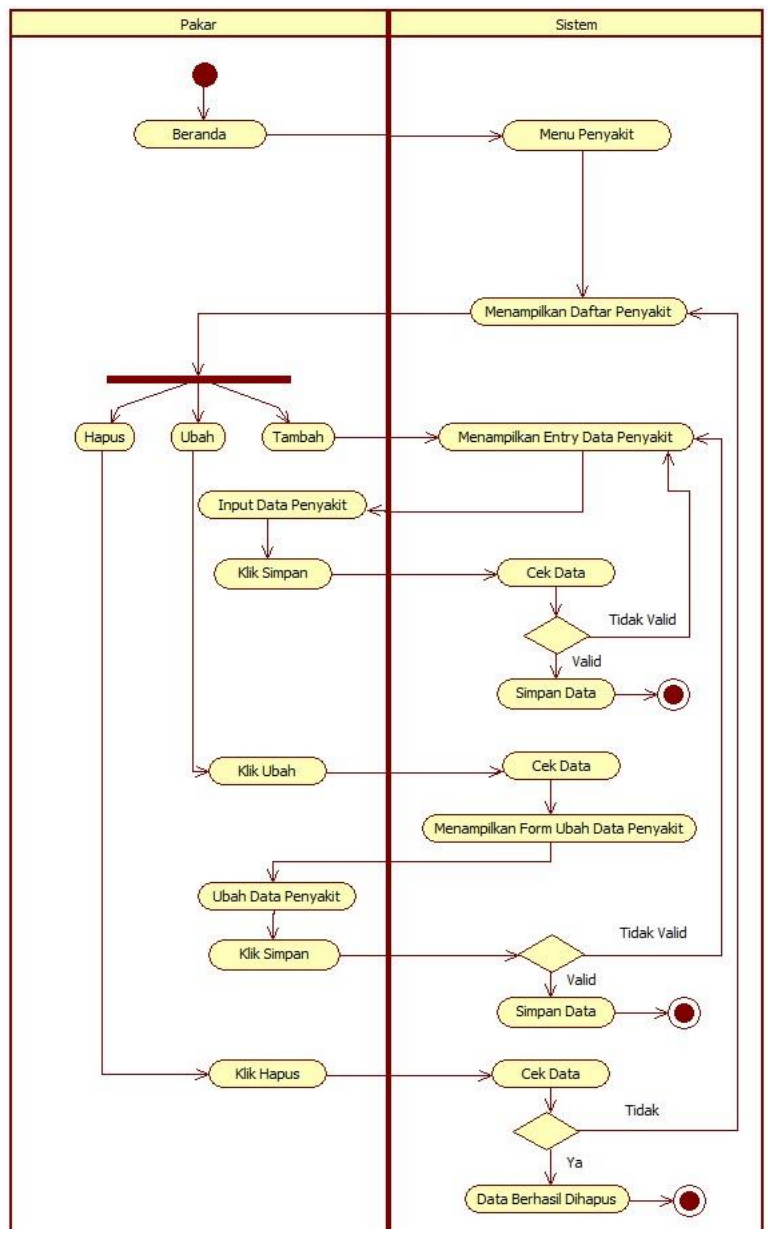

Gambar. 8. Diagram Aktivitas Menu Penyakit

f. Diagram Aktivitas Menu Relasi

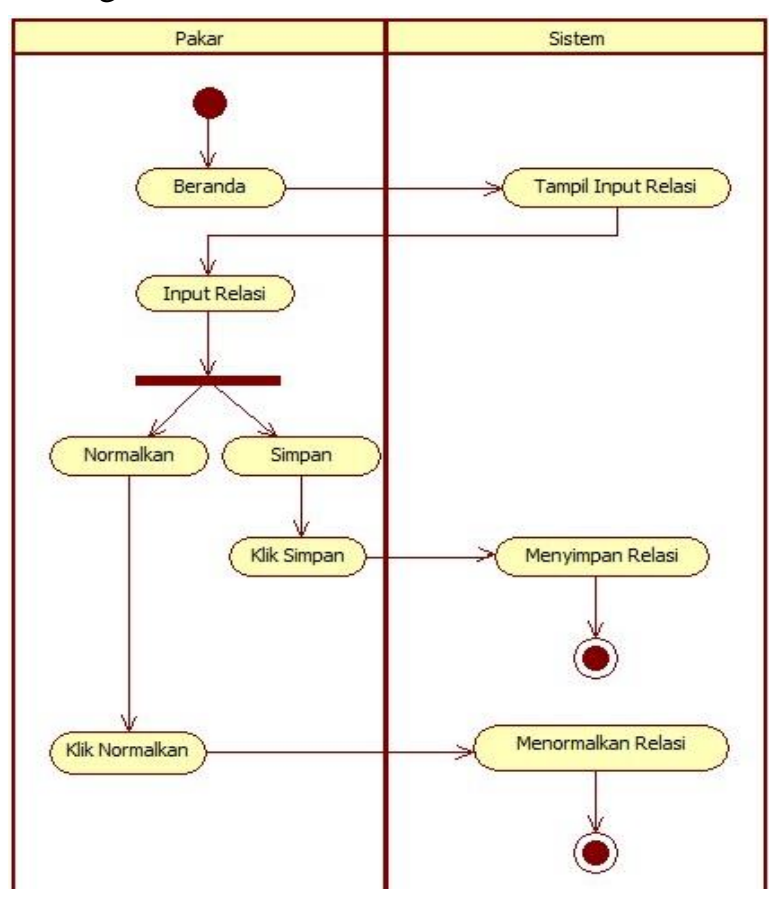

Gambar. 10. Diagram Aktivitas Menu Relasi 
g. Diagram Aktivitas Menu Laporan Konsultasi

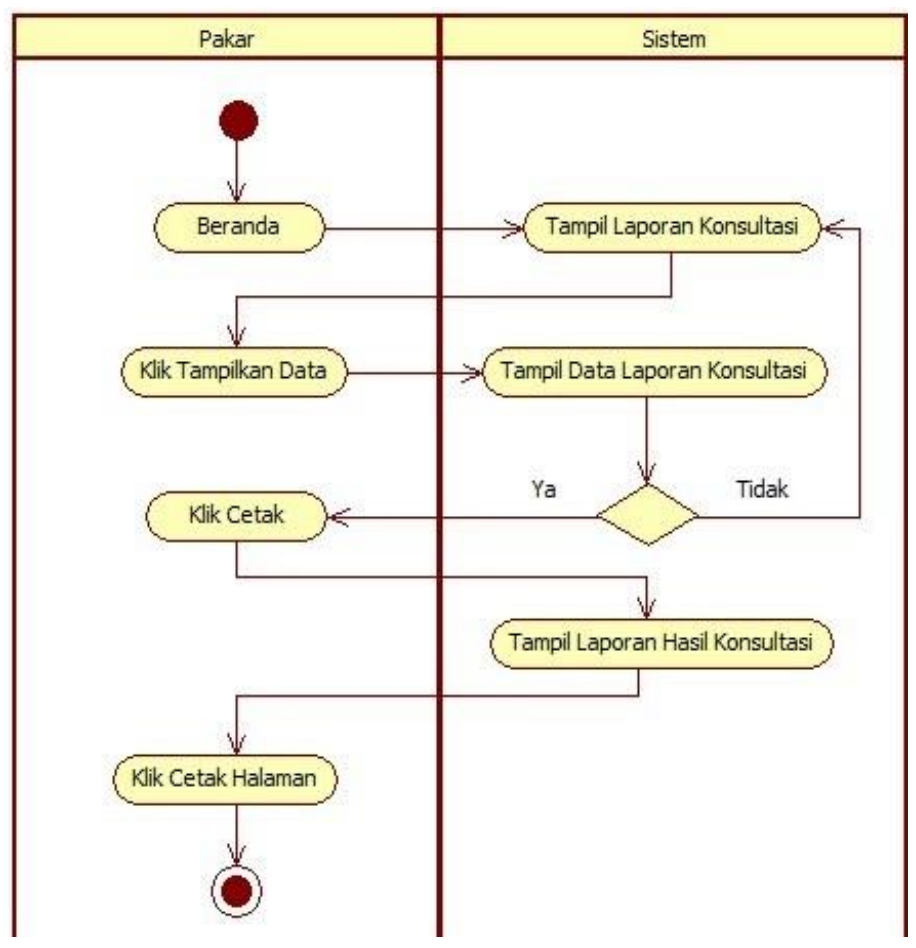

Gambar. 11. Diagaram Aktivitas Menu Laporan Konsultasi

\section{Diagram Kelas (Class Diagram)}

Tahap selanjutnya adalah pembuatan class diagram. Diagram class merupakan diagram yang menunjukkan kebutuhan class-class dalam suatu sistem program dimana class-class tersebut mengandung atribut-atribut dan operasi-operasi yang dibutuhkan. Class juga merupakan pembentuk utama dari sistem berorientasi objek karena class menunjukkan kumpulan objek yang memiliki atribut dan operasi yang sama. Class digunakan untuk mengimplementasikan interface. Dalam satu class, terdapat atribut dan operation yang berkaitan dengan class tersebut. Kemudian class-class yang telah didefinisikan satu sama lain melalui relasi yang terjadi antara class-class tersebut.

Menurut Satzinger Fokus domain class diagram adalah pada sesuatu dalam lingkungan kerja pengguna, bukan pada class perangkat lunak yang nantinya akan anda rancang [4].

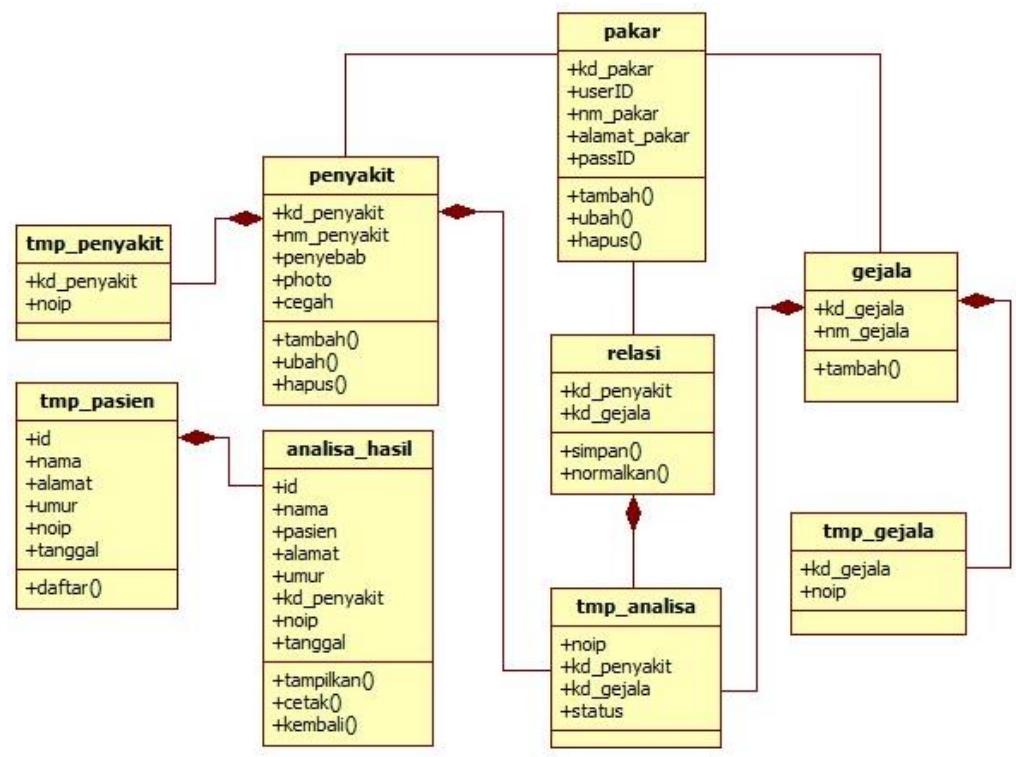

Gambar. 12. Class Diagram 


\section{B. Pembahasan}

1. Halaman Pasien (User)

a. Tampilan Beranda Pasien

Pada beranda pasien ini ditampilkan menu utama yang ada di dalam sistem dan juga menampilkan sebuah informasi tentang apa itu gizi, masalah gizi, dan faktor-faktor yang menyebabkan masalah gizi. Tampilan beranda pasien ditunjukkan pada Gambar 13.

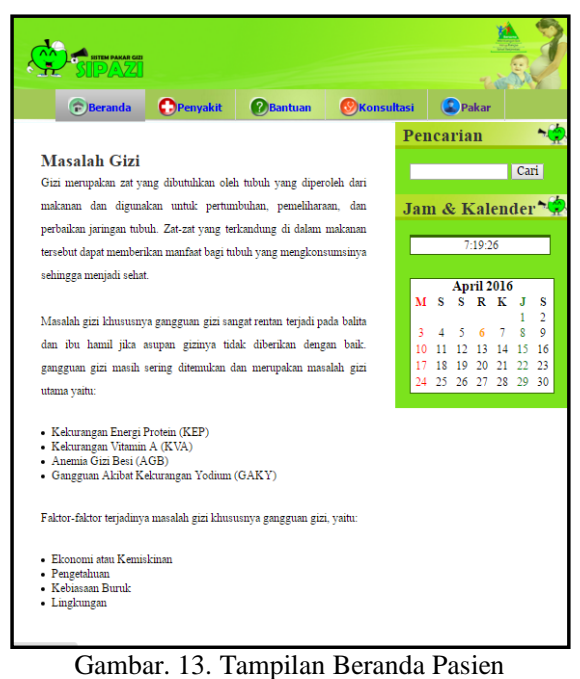

b. Tampilan Menu Penyakit

Pada tampilan menu penyakit ditampilkan jenis-jenis penyakit masalah gizi seperti Kekurangan Energi Protein, Anemia Gizi Besi, Kekurangan Vitamin A, GAKY Neurological Cretinism, GAKY Hypothiroid Cretinism. Tampilan menu penyakit ditunjukkan pada Gambar 14.

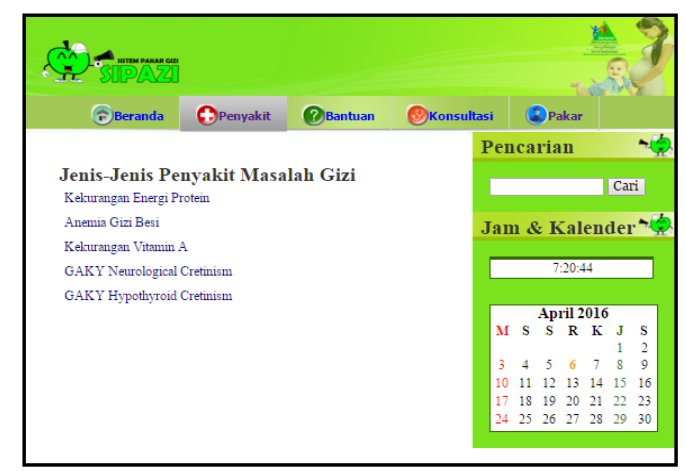

Gambar. 14. Tampilan Menu Penyakit

c. Tampilan Menu Bantuan

Pada halaman bantuan ditampilkan hak akses pengguna sistem pakar masalah gizi pada balita dan ibu hamil. Tampilan menu bantuan ditunjukkan pada Gambar 15.

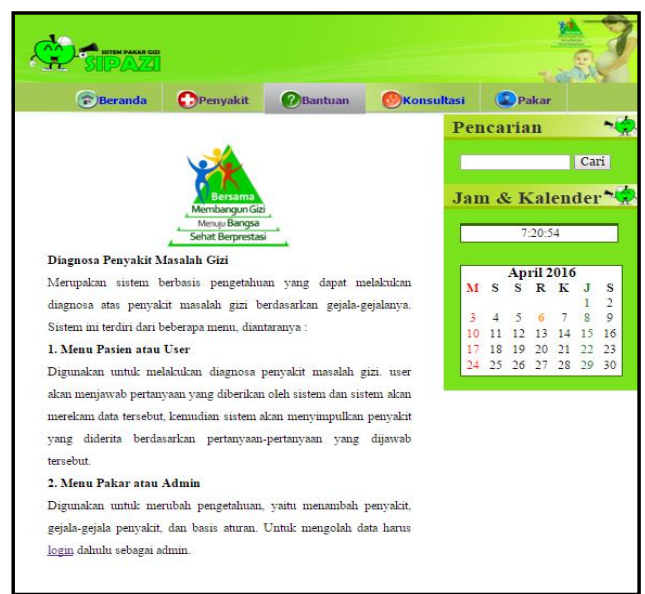

Gambar. 15. Tampilan Menu Bantuan 
d. Tampilan Menu Konsultasi

Pada tampilan menu konsultasi ditampilkan form pendaftaran pasien konsultasi, kemudian pasien mengisi form konsultasi untuk dapat berkonsultasi. Tampilan menu konsultasi ditunjukkan oleh Gambar 16-17.

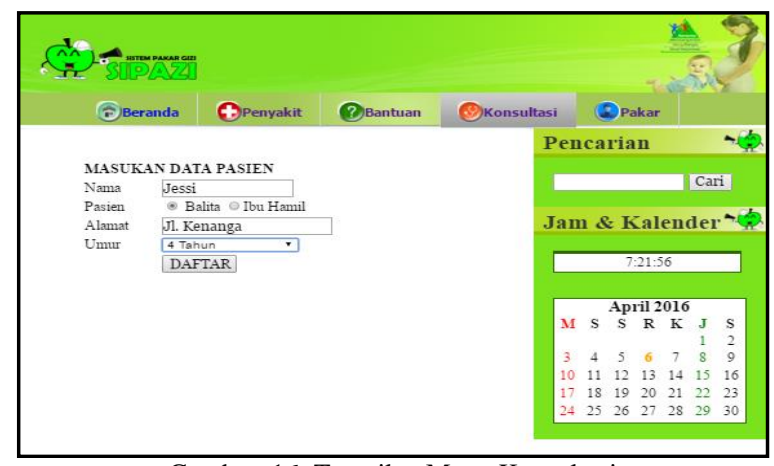

Gambar. 16. Tampilan Menu Konsultasi

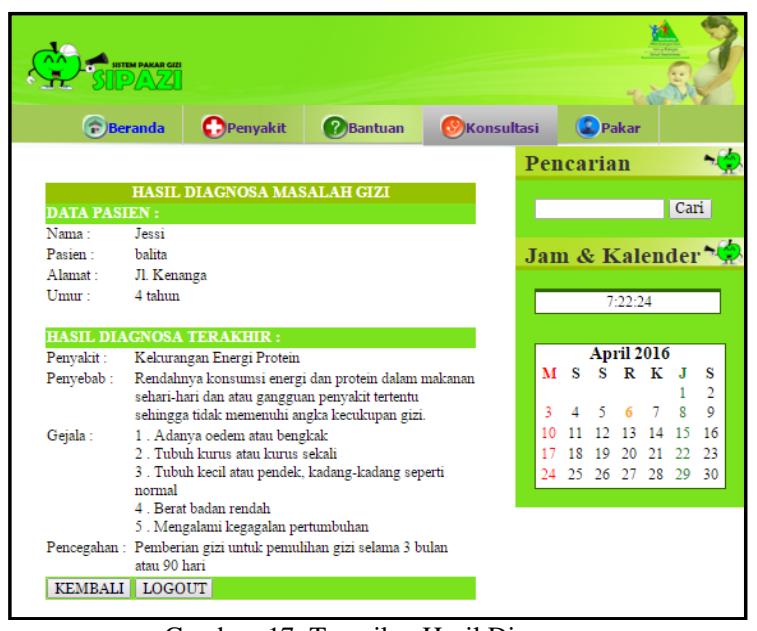

Gambar. 17. Tampilan Hasil Diagnosa

2. Halaman Pakar (Administrator)

a. Tampilan Menu Login Pakar ditunjukkan oleh Gambar 18.

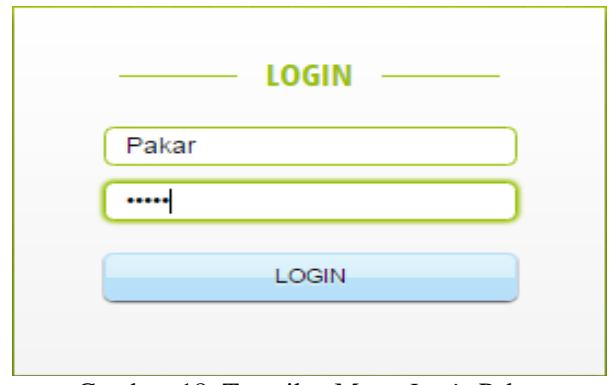

Gambar. 18. Tampilan Menu Login Pakar

b. Tampilan Beranda Pakar

Pada menu pakar ditampilkan data pakar, pakar dapat menambah pakar, mengubah dan menghapus data pakar seperti ditunjukkan pada Gambar 19. 


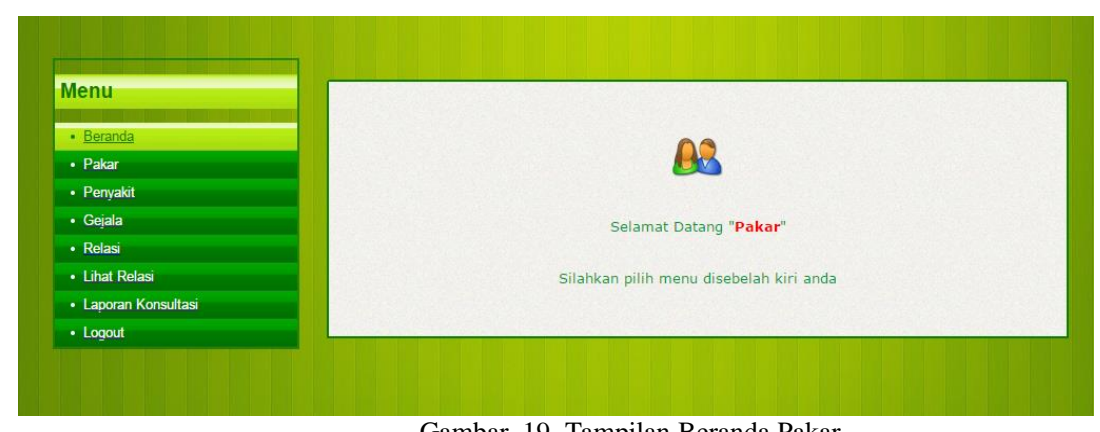

Gambar. 19. Tampilan Beranda Pakar

c. Tampilan Menu Penyakit

Pada tampilan menu penyakit ditampilkan data penyakit, pakar dapat menambah penyakit, mengubah dan menghapus data penyakit seperti ditunjukkan pada Gambar 20.

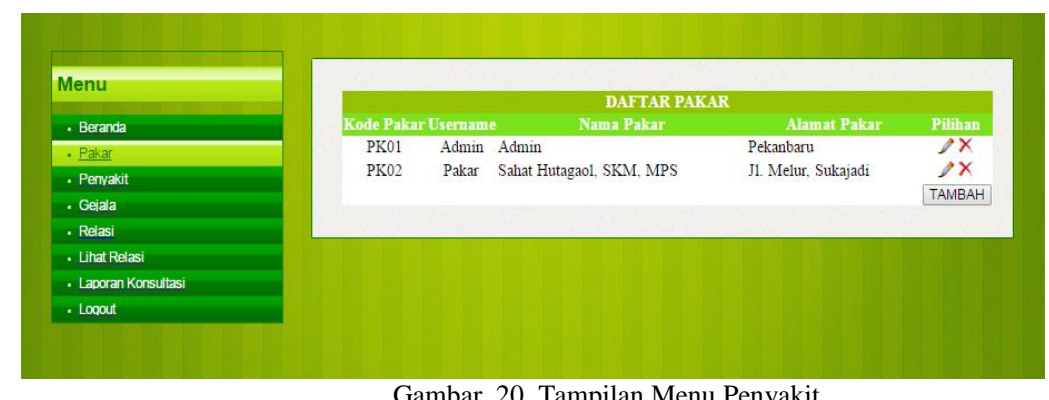

d. Tampilan Menu Gejala

Gambar. 20. Tampilan Menu Penyakit

Pada tampilan menu gejala ditampilkan data gejala, pakar hanya dapat menambah gejala seperti ditunjukkan pada Gambar 21.

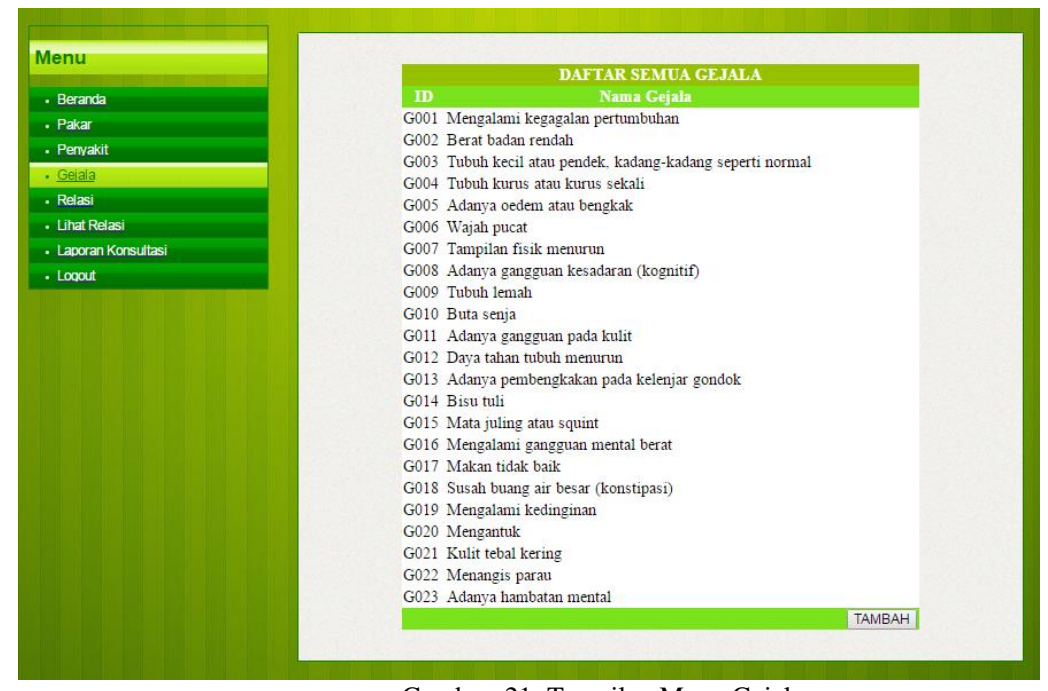

e. Tampilan Menu Relasi

Gambar. 21. Tampilan Menu Gejala

Pada tampilan menu relasi ditampilkan relasi antara penyakit dan gejala penyakit, dengan cara memasukkan relasi penyakit dan gejala penyakit. Tampilan menu relasi dapat dilihat pada Gambar 22.

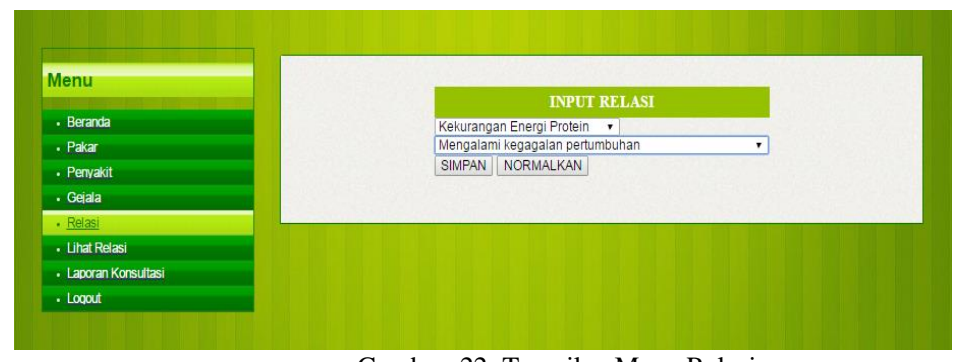

Gambar. 22. Tampilan Menu Relasi 


\section{f. Tampilan Menu Laporan Konsultasi}

Pada tampilan menu laporan konsultasi ditampilkan laporan konsultasi dari tanggal awal dan akhir konsultasi, jika pakar ingin mencetak laporan hasil laporan konsultasi, pakar mengklik cetak. Tampilan menu laporan dapat dilihat pada Gambar 23-24.

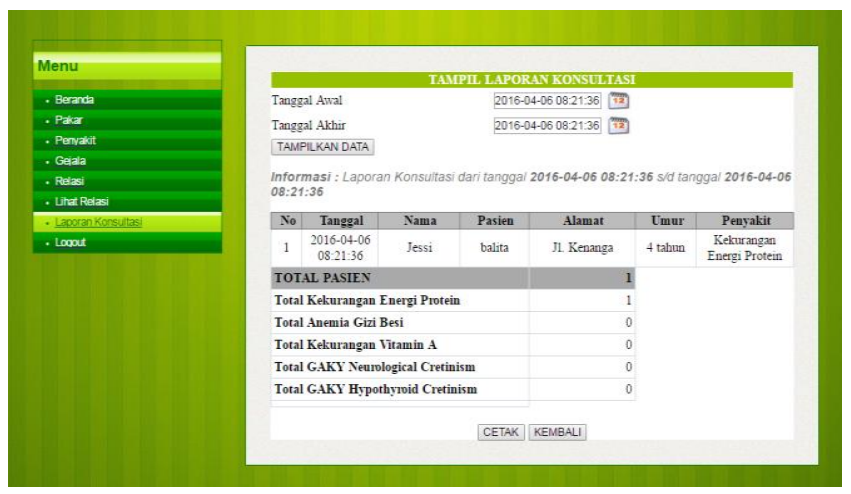

Gambar. 23. Tampilan Menu Laporan Konsultasi

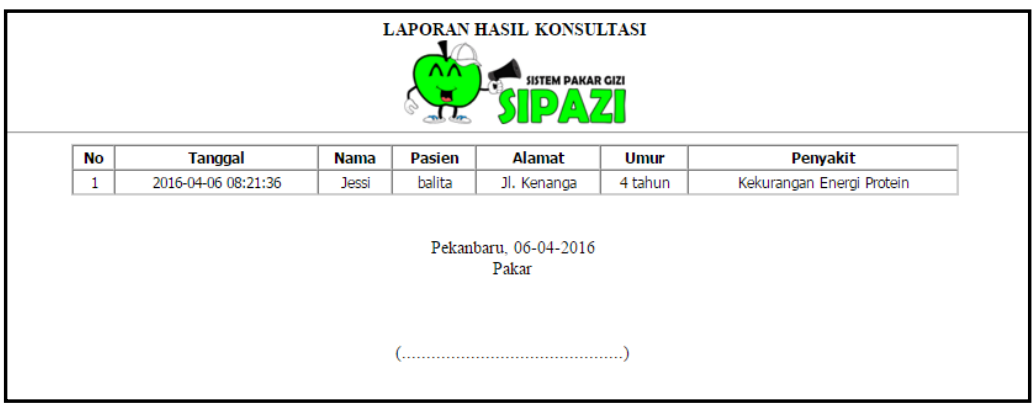

Gambar. 24. Tampilan Laporan Konsultasi

\section{KESIMPULAN}

Sistem Pakar menjadi salah satu solusi cepat bagi masyarakat untuk memperoleh solusi permasalahan dalam beraktivitas sehari-hari. Salah satu permasalahan yang sering muncul dalam kehidupan manusia masalah kesehatan terutama adalah masalah kesehatan gizi pada balita dan ibu hamil. Sistem pakar bisa memberi solusi tentang permasalahan kesehatan dan dengan dirancangnya aplikasi sistem pakar masalah gizi pada balita dan ibu hamil dapat membantu masyarakat dalam mendiagnosa masalah gizi sebelum ke dokter atau konsultan dan masyarakat dapat mengaksesnya dimana pun dan kapan pun. Aplikasi sistem Permasalahan gizi ini dapat dimanfaatkan oleh masyarakat untuk mengetahui penyakit, gejala dan pencegahannya, terutama masalah gizi pada balita dan ibu hamil.

\section{DAFTAR PUSTAKA}

[1] A. Proverawati dan S. Asfuah, "Buku Ajar Gizi untuk Kebidanan”, Yogyakarta, Nuha Medika, Indonesia, 2009

[2] B. Achmad, "Diktat Matakuliah Kecerdasan Buatan”, Yogyakarta, Universitas Gadjah Mada, Indonesia, 2006, hal. 10-11

[3] Badan Penelitian dan Pengembangan Kesehatan, "Riset Kesehatan Dasar (Riskesdas) 2013", Kemenkes RI, Jakarta, Indonesia, 2013

[4] E. Triandini dan I.G. Suardika, "Step By Step Desain Proyek Menggunakan UML", Yogyakarta, Penerbit Andi, Indonesia, 2012

[5] I. Sommerville, "Software Engineering 9th edition", Massachusetts, Pearson Education, USA, 2011

[6] Kusrini, "Sistem Pakar Teori dan Aplikasi", Yogyakarta: Penerbit Andi, Indonesia, 2006

[7] Kusrini, "Konsep dan Aplikasi Sistem Pakar", Yogyakarta: Penerbit Andi, Indonesia, 2008

[8] P. Destarianto dan P. Nugraheni, “Desain Sistem Pakar Mengindentifikasi Diare pada Balita”, Jember, SEMNASKIT 2015, Politeknik Neger Jember, Indonesia, 2015 
JTIULM - Volume 04, Nomor 1, April 2019: 21 - 34 